\title{
Morphometric Analysis of Kakoi River Watershed for Study of Neotectonic Activity Using Geospatial Technology
}

\author{
Francis Sangma, Guru Balamurugan \\ Centre for Geoinformatics, Jamsetji Tata School of Disaster Studies (JTSDS), Tata Institute of Social Sciences, Mumbai, India \\ Email: francis.sangma@gmail.com
}

How to cite this paper: Sangma, F. and Balamurugan, G. (2017) Morphometric Analysis of Kakoi River Watershed for Study of Neotectonic Activity Using Geospatial Technology. International Journal of Geosciences, 8, 1384-1403.

https://doi.org/10.4236/ijg.2017.811081

Received: October 10, 2017

Accepted: November 27, 2017

Published: November 30, 2017

Copyright ( 92017 by authors and Scientific Research Publishing Inc. This work is licensed under the Creative Commons Attribution International License (CC BY 4.0).

http://creativecommons.org/licenses/by/4.0/

\begin{abstract}
Morphometric analysis is defined as the quantitative measurement of landscape shape. Morphometric studies of a watershed helps the researcher to compare different landform and calculate the geomorphic indices that may be useful for identifying a particular characteristic such as the level of neotectonic activity in a watershed. The present study has been carried out in Kakoi River Watershed which is a part of Lower Subansiri River Basin in Assam. The study area is geo-dynamically unstable region characterized by active faults, continuing crustal movements and complicated structural region which fall under the seismic zone V of India. In recent century, the Lower Suabsiri River Basin has gone tremendous morphological changes due to active tectonics activities. After the Assam Earthquake of 1950, some of the rivers like Subansiri and its tributaries Dirgha, Kadam and Kakoi suddenly changed their channels giving birth to new channels. The present study is to examine the neotectonic domains and the changes of river course. The geomorphic indices such as Hypsometric Integral $(\mathrm{HI})$, Elongation ratio $\left(\mathrm{R}_{\mathrm{e}}\right)$, Asymmetry Factor (AF), Stream-length Gradient Index (SI), Mountain Front Sinuosity (Mfs), Basin shape index (Bs), Ratio of Valley floor width to Valley Height (Vf) and Channel sinuosity (S) etc. have been studied from remote sensing data. The results shows that the study area is under active tectonic area based on $\mathrm{Vf}(0.301), \mathrm{Rl}$ (0.461), Bs (3.6), Sl (165.73) and other parameters such as S (1.38) and Mfs (2.02) indicated as moderate active tectonic region. Utilization of geospatial technology and remote sensing data in the present study becomes more reliable and helpful in analyzing, monitoring and understanding the landform changes in a watershed.
\end{abstract}

\section{Keywords}

Morphometric, Geomorphic Indices, Neotectonics, Geospatial Technology 


\section{Introduction}

Morphometry is the mathematical and geometrical representation of earth's surface and shape dimension of earth's landform [1] [2] [3]. The study of morphometry analysis were initiated by Horton [4] [5] and Schumm [6] in the field of hydrology and are widely used by hydrologist and geomorphologist till date to study the spatial variability in the river basin. The morphometric analysis studies the basin processes and basin characteristic and describes the history of the river basin. It provides quantitative description of the river basin to understand initial slope, structural controls, geology and geomorphology [7]. And thus it proved to be initial steps to understand the basic of basin dynamics.

Morphometric analysis on watershed of a river basin is most preferable and advantageous as it is the basic unit of hydrology rather than analyzing on the individual channel or inconsistent segment areas of the basin [8]. Watershed is the appropriate unit to study several processes of the land surface because the major runoff is conveyed to single outlet [8]. The morphometric analysis of a watershed reveals valuable information regarding to hydrological processes, geomorphic processes and development of the land surface [9] [10]. Also it is helpful in predicting watershed maturity, erosion intensity, hydrological peak etc.

Morphometric analysis is very helpful to understand the underlying factors such as exogenesis and endogenesis factors which influence the hydrological behaviors [11]. The endogenesis processes are the complex integration of the effects of the vertical and horizontal motion of earth crust and erosional processes [12]. The morphometric analysis based on the geomorphic indices helps in establishing the endogenesis processes in a watershed [13] [14]. Several geomorphic indices combine together to highlight the tectonic activity and provide relative assessment on the degree of tectonic activities in a watershed area [15]. Tectonic plays an important role in evolution and modifying the drainage basin and is well reflected by structural, fluvial and morphometrics parameters [16]. The geomorphic indices have been developed as a basic reconnaissance tools to identify areas experiencing rapid tectonic deformation [15] [17].

The Indo-Ganga-Brahmaputra fluvial plain is subjected to active tectonics processes from the time of its form [18]. The active tectonic and climate change plays an important role in the development of geology and geomorphology of this region [19]. The Himalayan belt from Kashmir to Arunachal Pradesh is being tectonically active with frequent earthquakes and neo-tectonic movement [20]. As a result, the morphology of the river in this region is influences by tectonic activities.

The Brahmaputra River is one of the largest rivers in the world and is characterized by heavy floods and sediment load, flood damages and instability [20]. Brahmaputra basin is located in a geo-dynamically unstable region characterized by active faults, continuing crustal movements and complicated structural region which fall under the seismic zone V of India [21]. According to plate tectonics, the Indian plate moving in the north-northeasterly direction is under 
thrusting the Eurasian plate and is causing deformation and instability in the Brahmaputra basin. The flood plain of Brahmaputra, domesticated over the centuries suddenly face new challenge due to the earthquake of 1897 and 1950. The channels of the Brahmaputra underwent several major transformations as short as well as long terms of landforms. This includes either shifting of the river courses or rise in the river bed.

Large and small tributaries from both north and south joined the Brahmaputra River while flowing through Assam, India. The northern tributaries such as Subansiri River, Ranganadi River, Jia Bhareli River, Sankosh River, Pagladia River, and the Manas River come from fragile Himalayas with highest rainfall and have steeper slopes [21]. In general, the drainage anomalies characterized by migration of river course, paleo channels, etc. are common in the northern tributaries of Brahmaputra River [22] [23] [24] [25].

The Subansiri River is one of the important north-bank tributaries of Brahmaputra River. In the recent century, the lower Subansiri River basin has gone tremendous morphological changes due to active tectonics activities. After the Assam Earthquake of 1950, some of the rivers like Subansiri and its tributaries Dirgha, Kadam and Kakoi suddenly changed their channels giving birth to new channels destroying villages, agricultural fields or tea-plantation [26].

Geospatial technologies such as GIS and remote sensing data have been used successfully to evaluate the terrain and morphometric parameters of a watershed with easier and better accuracy [27]. The analysis for the present study is carried out by GIS and remote sensing data to calculate the geomorphic indices of the watershed digitally and precisely. This helps to generate data to understand the watershed characteristics and changes of the landform. Thus it provides an insight into hydrologic condition of the watershed necessarily for developing watershed management strategies [27] [28].

The main objectives of the morphometric analysis of the Kakoi River watershed are:

- To examine the active tectonic domains in the watershed;

- To examine the river course changes due to the active tectonic activities using geospatial technology.

\section{Study Area}

The Kakoi River watershed extends from $27^{\circ} 25^{\prime} 23.24^{\prime \prime} \mathrm{N}$ latitude to $27^{\circ} 14^{\prime} 12.83^{\prime \prime} \mathrm{N}$ latitude and from $94^{\circ} 5^{\prime} 45.79 " \mathrm{E}$ longitude to $94^{\circ} 6^{\prime} 46.55^{\prime \prime} \mathrm{E}$ longitude. About $29.3 \%$ of the Kakoi River is located in the Papum Pare district of Arunachal Pradesh and rest is located in the Lakhimpur district of Assam (Figure 1). The total area of the watershed is about $140.11 \mathrm{sq} . \mathrm{km}$. The source of Kakoi River is from the Siwalik range of lower Himalaya. The river travels about $38.17 \mathrm{~km}$ from the source till it merges with Subansiri River at Badhakarh Kuchiamari (Figure 2). The Kakoi River flows about $11.17 \mathrm{~km}$ in the hilly terrain of Arunachal Pradesh creating deep gorge and rest flows in the alluvial plains of Assam with shallow depth. The minimum height is about $21 \mathrm{~m}$ and the maximum is about $1728 \mathrm{~m}$ 


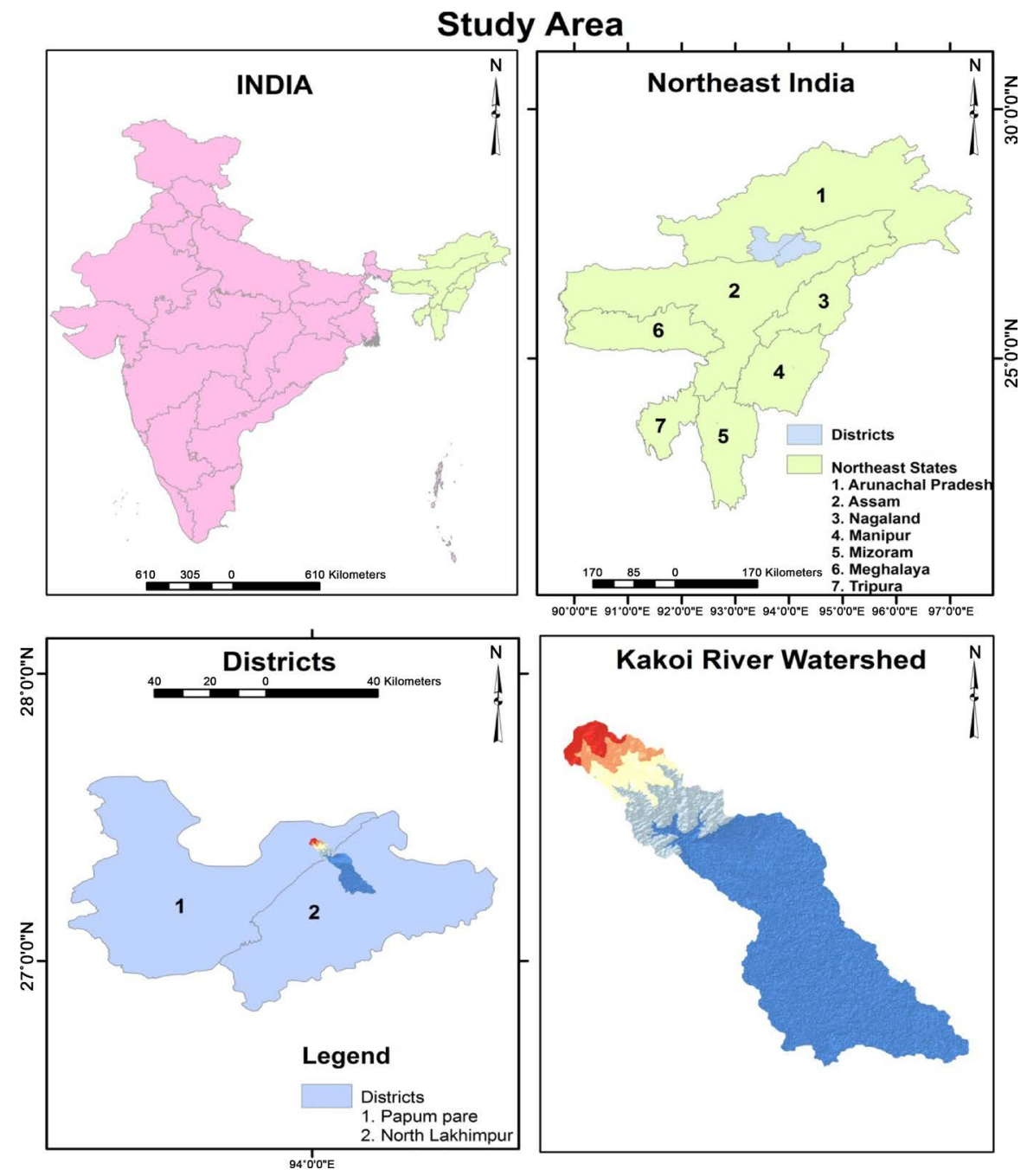

Figure 1. Study area of Kakoi River Watershed, Assam, India.

above the mean sea level (Figure 2).

The study area can be divided into the three physiographical characteristics, i.e., the hilly tract, the foothill region and alluvial flood plain [29]. The hilly tracts comprise Siwalik sediments of lesser Himalayas. The foothill region is characterized by older terrace deposit called Bhabar Zone which runs parallel to the foot hills of the lower Himalaya [30]. This terrace deposits are characterized by undulating surface comprising boulders, pebbles of quartzitic and gneissic rocks with fine sand, silt and clay acts as metrix. The percentage of the boulders and pebbles diminish southwards from the foothills and the percentage of the sand and the silt increases towards the south [30]. The third physiographical characteristics of the study area is alluvial flood plain consists of younger and older alluvial deposits (Figure 2). This region represents various sub-features such as Palaeochannel, swamps/marshy land, river terraces, flood plains, point bars, channels bars and river channel etc. The slope of the study area drops from the northern and eastern corner to the south.

The climatic condition of the study area is subtropical and humid with high 
rainfall. The study area receives SW monsoon rainfall from the month of April and continues up to September/October. The average annual rainfall is about $1300 \mathrm{~mm}$ [31]. The highest rainfall area is located near the foothills of Arunachal

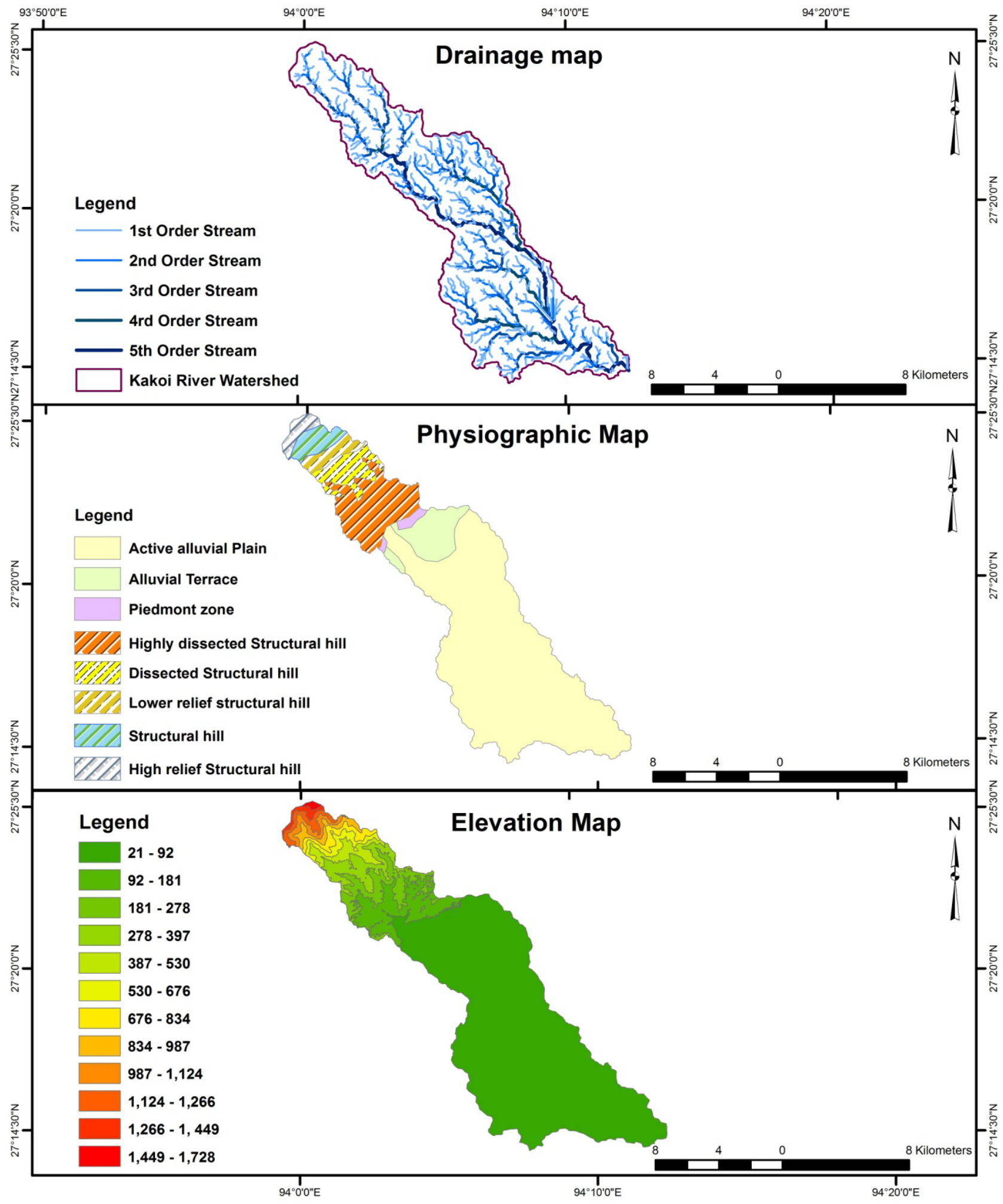

Figure 2. Drainage Map, Physiographic Map, Elevation Map. 
Pradesh, i.e., the northern part of the study area. The summer is hot and humid, starting from the month of March and extending till October. The average summer temperature is about $29^{\circ} \mathrm{C}$ to $36^{\circ} \mathrm{C}$ [31]. The relative humidity is about 74 to 89 percent with a mean of 81 percent [30]. The winter is characterized by scanty rainfall and foggy morning and afternoon with minimum temperature of $10^{\circ} \mathrm{C}[31]$.

\section{Materials and Methodology}

The present work is base on the morphometric analysis of Kakoi River Watershed to examine the neotectonic activity and river course changes. To access the morphometric parameters, the Cartosat DEM (2015) with resolution 1 arc second $(30 \mathrm{~m})$ has been used. The morphometric parameters have been generated in GIS environment using ArcGIS 9.3 software. The Cartosat DEM has been used for the present study because it gives higher value of stream parameters than other DEM [32] [33] [34].

The morphological characteristics of the watershed are calculated with ArcGIS 9.3 software and it provides main input for the present research (Table 1). The Basin area (A) is the entire area that is comprised by the drainage basin boundary. Basin perimeter $(\mathrm{P})$ is the total length of the basin boundary and basin perimeter is the length of the main stream order, plus the length of the extension between the end of the main stream order until the longer point of the basin, parallel to the main stream order.

The stream number is counted according to Horton [5] and was developed by Strahler [35], which is most commonly used method today (Table 2). In this smallest headwater tributaries are called first order stream. When two first order streams meet, they together create second order Stream. And again when two second order streams meet, they create third order stream and so on.

\subsection{Mountain Front Sinuosity (Smf)}

Bull and Mc Fadden [17] proposed Mountain front sinuosity (Smf) to study the

Table 1. Morphological characteristics.

\begin{tabular}{ccc}
\hline Sl no. & Morphological parameter & Value \\
\hline 1 & Basin area (A) (sq. km) & 140.11 \\
2 & Basin perimeter $(\mathrm{P})(\mathrm{km})$ & 82.03 \\
3 & Basin length $(\mathrm{Lb})(\mathrm{km})$ & 29.25 \\
\hline
\end{tabular}

Table 2. Stream order and stream length.

\begin{tabular}{cccccc}
\hline Stream ordering & $\begin{array}{c}\mathbf{1}^{\text {st }} \text { order } \\
\text { stream }\end{array}$ & $\begin{array}{c}\mathbf{2}^{\text {nd }} \text { order } \\
\text { stream }\end{array}$ & $\begin{array}{c}\mathbf{3}^{\text {rd }} \text { order } \\
\text { stream }\end{array}$ & $\begin{array}{c}\mathbf{4}^{\text {th }} \text { order } \\
\text { stream }\end{array}$ & $\begin{array}{c}\mathbf{5}^{\text {th }} \text { order } \\
\text { stream }\end{array}$ \\
\hline $\begin{array}{c}\text { No. of streams } \\
\text { Stream length }(\mathrm{km})\end{array}$ & 461 & 101 & 22 & 5 & 1 \\
Mean stream length $(\mathrm{km})$ & 0.397 & 0.867 & 2.207 & 4.087 & 28.313 \\
\hline
\end{tabular}


balance between the tendency of stream and slope processes produce an irregular mountain front and vertical active tectonics that tends to produce a prominent straight front. Mountain front sinuosity (Smf) is the ratio of the total length of the mountain front as measured along the foot of a mountain and the straight line length of the mountain front.

$$
\mathrm{Smf}=\frac{\mathrm{Lmf}}{\mathrm{Ls}}
$$

where, Smf = Mountain front sinuosity; Lmf $=$ Total length of the mountain front; Ls = Straight line length of the mountain front.

\subsection{Channel Sinuosity $(S)$}

Channel sinuosity is the ratio of channel length and river valley length. The following formula is used to calculate channel sinuosity $(\mathrm{S})$

$$
\mathrm{S}=\frac{\mathrm{SL}}{\mathrm{VL}}
$$

where, $\mathrm{S}=$ Channel Sinuosity; SL = the stream length; VL = the valley length.

According to Leopold and Wolman [36], the sinuosity ratio is where, $\mathrm{P}<1.05$ is almost straight; $1.05 \leq \mathrm{P}<1.25$ is windy; $1.26 \leq \mathrm{P}<1.50$ is twisty; $1.51 \leq \mathrm{P}$ is meandering.

\subsection{The Ratio of Valley Floor Width to Valley Height (Vf)}

The valley floor width to valley height ratio is another index to access the area on the basis of the tectonic activity [15] [17]. This index uses one vertical and one horizontal dimension at a given point along the stream in the erosion system. The valley floor width and valley height ratio is defined as follows

$$
\mathrm{Vf}=2 \mathrm{Vfw} /[(\text { Eld }- \text { Esc })+(\text { Erd }- \text { Esc })]
$$

where, $\mathrm{Vfw}=$ the width of the valley floor; Esc = the elevation of the valley floor or stream channel; Eld = the elevation of the left valley; Erd = the elevation of the right valley.

\subsection{Stream Length-Gradient Index (SL)}

The stream length-gradient index (SL) is calculated along a river and used to evaluate the erosion resistance of the available rocks and relative intensity of active tectonics [37]. The stream length-gradient index is proposed by Hack [38]. To calculate this index, the following formula is used

For a Section of watershed

$$
\mathrm{SL}=\left(\frac{\Delta \mathrm{H}}{\Delta \mathrm{L}}\right) \times \mathrm{L}
$$

For Total watershed

$$
\mathrm{SL}=\frac{\Delta \mathrm{H}}{\ln \mathrm{L}}
$$

where, $\Delta \mathrm{H}=$ the change in elevation of the reach; $\Delta \mathrm{L}=$ the length of the reach; $\mathrm{L}$ 
$=$ the total length from midpoint of the reach of interest upstream to the highest point on the channel.

For the present study, total watershed formula has taken as consideration.

\subsection{Elongation Ratio $\left(R_{e}\right)$}

Relative young basins in active tectonic areas are more tend to elongation in shape. Ratio of diameter of a circle (Dc) having same area as the basin to the maximum length (Lbm) of the basin [6]. The calculation formula is:

$$
\mathrm{R}_{\mathrm{e}}=\mathrm{Dc} / \mathrm{Lbm}=2 \mathrm{~A} / \pi / \mathrm{Lbm}
$$

where, $\mathrm{Dc}=$ the perimeter of the basin; $\mathrm{Lbm}=$ basin length of the basin.

Values of the $\mathrm{Rl}$ index less than 0.5 indicate tectonically active regions, values between 0.5 to 0.75 moderate active regions and values larger than 0.75 inactive ones [39].

\subsection{Drainage Basin Shape Index (Bs)}

Drainage basin shape index is defined as the ratio of the length of the basin to the width of the basin at its widest point.

$$
\mathrm{Bs}=\mathrm{Bl} / \mathrm{Bw}
$$

where, $\mathrm{Bs}=$ Basin shape; $\mathrm{Bl}=$ length of the basin; $\mathrm{Bw}=$ width of the basin.

High value index imply elongated basin indicating high tectonic processes and low value index imply circular basin indicate less active tectonic processes [17] [40].

\subsection{Hypsometric Integral (HI)}

Hypsometric integral, a dimensionless parameter is proposed by Strahler [35]. Hypsometric analysis is the study of the distribution of horizontal cross-sectional area of the landmass with respect to elevation. HI is calculated by following formula

$$
\mathrm{HI}=\frac{\text { mean elevation }- \text { minimum elevation }}{\text { maximum elevation }- \text { minimum elevation }}
$$

The results of $\mathrm{HI}$ indicate three stages of the basin: 1) Basin having $\mathrm{HI}>0.5$ representing with deep incision and slight erosion from active tectonics; 2) Basin having $0.4<\mathrm{HI}<0.5$ indicate approximate equilibrium and an intermediate stage of incision and erosion from recent active tectonic and; 3) Basins having $\mathrm{HI}<0.4$ characterized by low relief and severe erosion [37] [40].

Here, hypsometric curve is used to show the relationship between elevation of the basin and the area of the basin. Both hypsometric integral and hypsometric curve is important to show the conditions of the basin.

\subsection{Asymmetry Factor (AF)}

The asymmetry factor developed to detect tectonic tilting transverse to flow at a drainage basin. The equation of asymmetry factor is 


$$
\mathrm{AF}=100\left(\frac{\mathrm{Ar}}{\mathrm{At}}\right)
$$

where, Ar = the area of the basin (facing downstream) of the trunk stream; At = the total area of the drainage basin.

$\mathrm{AF}$ index equal to $50 \%$ the drainage network formation is under stable condition. If $\mathrm{AF}>50 \%$ indicate tilting left downstream and $\mathrm{AF}<50 \%$ indicate titling right Downstream. Such tilting is result of active tectonics rather than lithological factor [41]. The absolute difference (AF-50) is taken as consideration to evaluate the tectonic influence in the drainage basin. AF-50 value close to 0 indicates less active tectonic activity while value increase from 0 indicates higher tectonic activity [40].

\subsection{Transverse Topographic Symmetry Factor (T-Vector)}

Another quantitative index to evaluate basin symmetry is the transverse topographic symmetry following the basic technique presented by Cox [42]. T-factor index is calculated with formula

$$
\mathrm{T}=\mathrm{Da} / \mathrm{Dd}
$$

where, $\mathrm{Da}=$ the distance from the midline of the drainage basin to the midline of the active meander belt; $\mathrm{Dd}=$ the distance from the basin midline to the basin divide.

This above method is applied to the main stream of the basin. To calculate the T-vector altogether 102 points were taken considering at the confluence points of all the major tributaries of the main river.

The Analytical Hierarchy Process (AHP) was introduced by Saaty [43] and most widely spread and used theory for decision making. It is used to analyze complex problem with multi criteria. In the present study, Analytical Hierarchy Process (AHP) has been used for discriminating basin with active tectonic control.

\section{Data Analysis and Results}

The Kakoi river is $5^{\text {th }}$ order basin which traverse through high land, mid land and low land. It is observed that all the stream of the Kakoi watershed follow Horton's Law of stream number (Figure 3). According to Horton's law the number of streams in different orders in a given drainage basin tends to closely approximate an inverse geometric series in which the first term is unity. The drainage pattern is dendrite and the tributaries are oriented mostly in North-east direction.

It is observed that the stream length of the Kakoi River Watershed follows Horton's law of stream length. But an anomaly has observed in the stream length of the Kakoi river watershed. It is found that $1^{\text {st }}, 4^{\text {th }}$ and $5^{\text {th }}$ order stream shows some deviation from the straight line which according to Horton's law is due to structural control of the basin (Figure 4).

The morphometric indices that are taken as consideration to determine the 


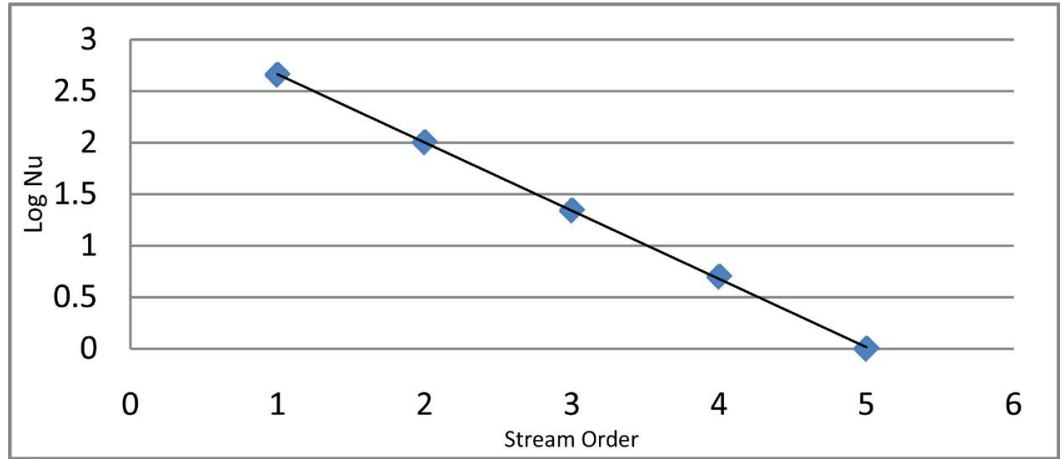

Figure 3. Regression of logarithm of number of stream segments $(\mathrm{Nu})$ versus stream order (u) for Kakoi River Watershed.

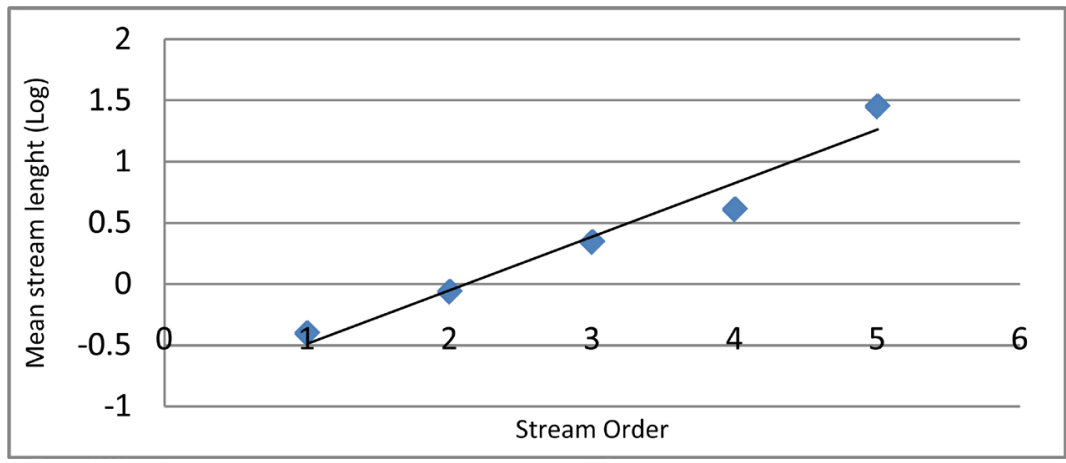

Figure 4. Regression of logarithm of mean stream length $(\mathrm{Nu})$ versus stream order $(\mathrm{u})$ for Kakoi River Watershed.

Table 3. Morphometric indices.

\begin{tabular}{ccc}
\hline Parameters & Value & Description \\
\hline Mountain front sinuosity (Mfs) & 2.02 & Moderate active tectonic \\
Channel sinuosity (S) & 1.38 & Moderate active tectonic \\
Valley floor width to valley height ratio (Vf) & 0.301 & Active tectonic \\
Elongation ratio ( $\left.\mathrm{R}_{\mathrm{e}}\right)$ & 0.461 & Active tectonic \\
Drainage basin shape index (Bs) & 3.6 & Active Tectonic \\
Hypsometric integral (HI) & 0.45 & Moderate active tectonic \\
Stream length-gradient index (Sl) & 165.73 & Active tectonic \\
Asymmetry factor (Af) & 51.51 & Low active tectonic \\
\hline
\end{tabular}

tectonic activity in the Kakoi River Watershed are shown in Table 3. The value of mountain front sinuosity is 2.02 . Lower the value of mountain front sinuosity indicate high tectonics activity while higher the value indicates less tectonic activity. The present result of mountain front sinuosity show moderate tectonics activities along the mountain front. Both tectonic and lithology plays important role in modifying the mountain front of the studied watershed. The channel sinuosity value is 1.38 . The sinuosity value suggests that the Kakoi River is twisty and it flows along the flood plain which is influence by both lithology and tectonic activity. 
The value for the valley floor width to valley height (Vf) ratio is 0.301 . The $\mathrm{Vf}$ ratio indicate that the basin is the valley is $\mathrm{V}$ shape and is tectonically active. The value of elongation ratio of the basin is 0.461 . The ratio indicates that the basin is elongated and control mainly by active tectonic. Low value of the ratio implies the effect of trusting and faulting within the basin. The basin shape index of the Kakoi River Watershed is 3.6. Higher basin shape index indicate active tectonic and the basin is elongated. Lower the value, basin shape is circular with low tectonic activities.

The hypsometric integral value for the Kakoi Watershed is 0.45 . The result of the $\mathrm{HI}$ indicates that the basin area is an intermediate stage of incision and high erosion. The Hypsometric Curve of the basin area is concave which suggest that the basin reach the old stage with low relief (Figure 5). The figure shows that the northern part is very steep while the southern part is lowered gently, which is controlled by the lithology while the northern part of the basin is more incline to tectonic activity.

The asymmetric integral value for the right bank of the basin is 51.51 percent and the left bank asymmetry integral value is 48.49 percent (Figure 6). The asymmetric integral value is close to 50 indicate that the basin area is highly dissected, highly eroded and have significant impact from the recent active tectonic activity. The river basin is tilting right downstream and such tilting is result of lithological factors (e.g. dipping sedimentary layers) rather than tectonics. The asymmetric integral value of the right bank of the present basin is higher than 50 as such the river course flows close to the left of the watershed. The absolute AF-50 difference is 1.51 indicate that the basin has slight influence of recent tectonic activity.

The T-index value for the present study varies from 0.01 to 0.92 along the main river course (Table 4). The magnitude of T-index values range from 0 to 1. The increase $\mathrm{T}$-index values from 0 to 1 indicate that the lateral migration of the river course, from the midline axis of the basin. Thus indicate the tilting of the basin is in the direction of the migration. Most of the points suggest that the migration of the river happens in north-west and south-west direction (Figure 7). One point along the river (Sl. No. 100) indicates perfect symmetry as the

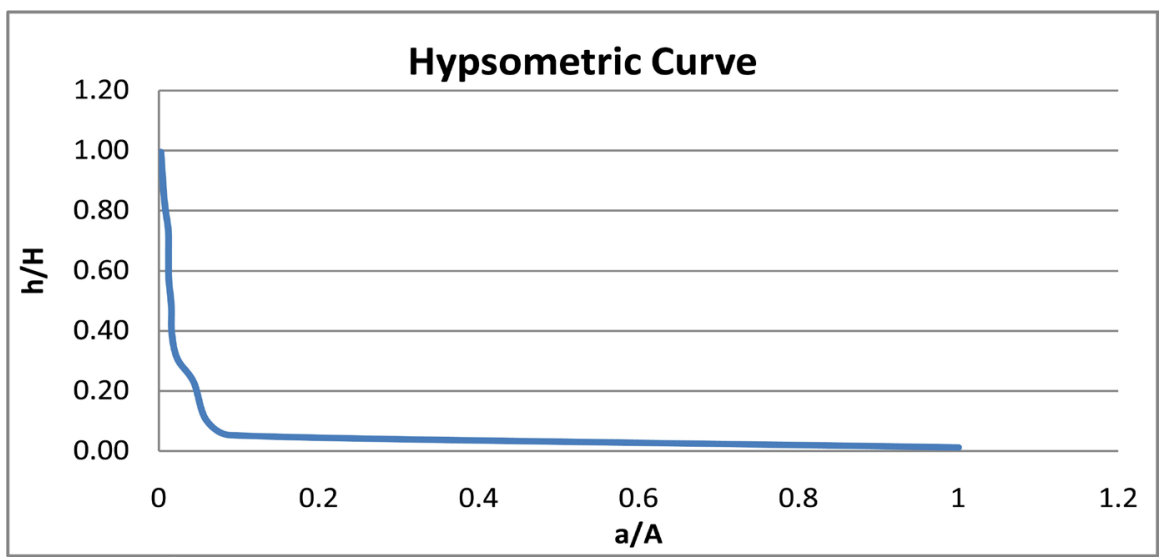

Figure 5. Hypsometric curve. 


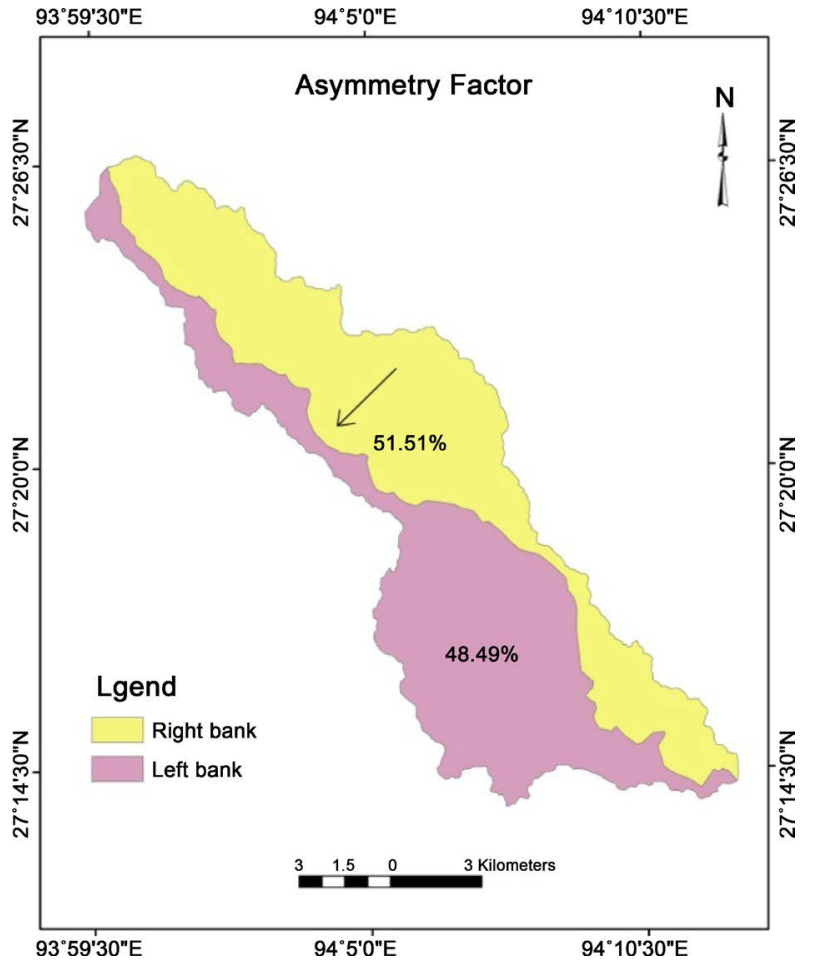

Figure 6. Asymmetry factor.

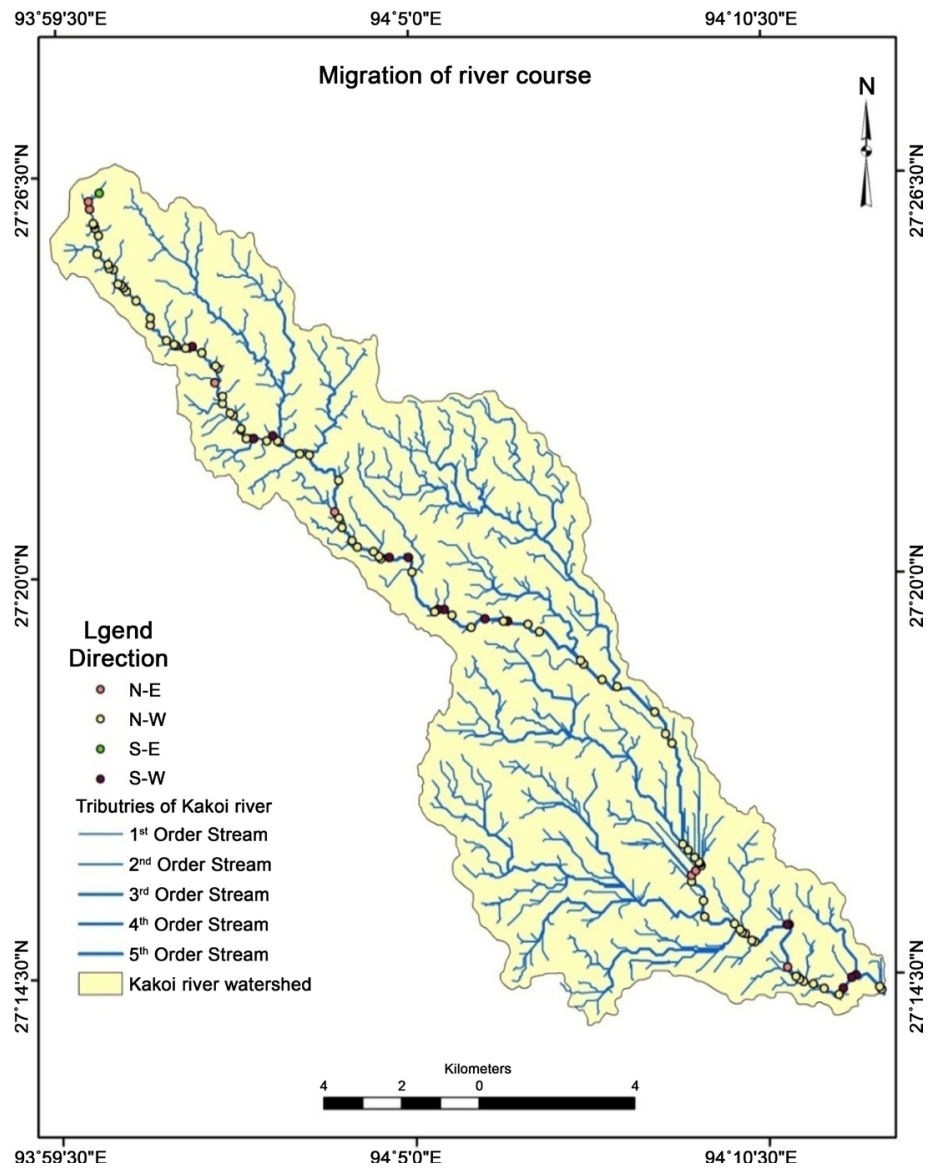

Figure 7. Migration of the river course. 
Table 4. T-index for Kakoi River Watershed.

\begin{tabular}{|c|c|c|c|c|}
\hline Sl. no & Bearing (DMS) & Azimuth & T-index & Direction \\
\hline 1 & $42^{\circ} 20^{\prime} 35.2^{\prime \prime}$ & $317^{\circ} 39^{\prime} 24.8^{\prime \prime}$ & 0.31 & N-W \\
\hline 2 & $63^{\circ} 35^{\prime} 41.4^{\prime \prime}$ & $296^{\circ} 24^{\prime} 18.6^{\prime \prime}$ & 0.17 & N-W \\
\hline 3 & $60^{\circ} 13^{\prime} 46.5^{\prime \prime}$ & $240^{\circ} 13^{\prime} 46.5^{\prime \prime}$ & 0.05 & S-W \\
\hline 4 & $37^{\circ} 55^{\prime} 14.4^{\prime \prime}$ & $217^{\circ} 45^{\prime} 14.4^{\prime \prime}$ & 0.06 & S-W \\
\hline 5 & $35^{\circ} 1^{\prime} 17.2^{\prime \prime}$ & $215^{\circ} 1^{\prime} 17.2^{\prime \prime}$ & 0.42 & S-W \\
\hline 6 & $68^{\circ} 45^{\prime} 57.5^{\prime \prime}$ & $291^{\circ} 14^{\prime} 2.5^{\prime \prime}$ & 0.6 & N-W \\
\hline 7 & $66^{\circ} 26^{\prime} 6.3^{\prime \prime}$ & $293^{\circ} 34^{\prime} 53.7^{\prime \prime}$ & 0.54 & N-W \\
\hline 8 & $76^{\circ} 34^{\prime} 51.9^{\prime \prime}$ & $286^{\circ} 25^{\prime} 8.1^{\prime \prime}$ & 0.53 & N-W \\
\hline 9 & $61^{\circ} 19^{\prime} 10.9^{\prime \prime}$ & $298^{\circ} 40^{\prime} 49.1^{\prime \prime}$ & 0.64 & N-W \\
\hline 10 & $53^{\circ} 49^{\prime} 25.7^{\prime \prime}$ & $306^{\circ} 10^{\prime} 34.3^{\prime \prime}$ & 0.67 & N-W \\
\hline 11 & $42^{\circ} 19^{\prime} 53.8^{\prime \prime}$ & $317^{\circ} 40^{\prime} 6.2^{\prime \prime}$ & 0.64 & N-W \\
\hline 12 & $2^{\circ} 22^{\prime} 59.7^{\prime \prime}$ & $2^{\circ} 22^{\prime} 59.7^{\prime \prime}$ & 0.48 & N-E \\
\hline 13 & $89^{\circ} 27^{\prime} 34.0^{\prime \prime}$ & $269^{\circ} 27^{\prime} 34^{\prime \prime}$ & 0.1 & S-W \\
\hline 14 & $61^{\circ} 53^{\prime} 25.2^{\prime \prime}$ & $241^{\circ} 52^{\prime} 25.2^{\prime \prime}$ & 0.08 & S-W \\
\hline 15 & $70^{\circ} 4^{\prime} 58.9^{\prime \prime}$ & $289^{\circ} 55^{\prime} 1.1^{\prime \prime}$ & 0.24 & N-W \\
\hline 16 & $42^{\circ} 19^{\prime} 28.6^{\prime \prime}$ & $317^{\circ} 30^{\prime} 31.5^{\prime \prime}$ & 0.25 & N-W \\
\hline 17 & $70^{\circ} 4^{\prime} 53.7^{\prime \prime}$ & $289^{\circ} 55^{\prime} 6.3^{\prime \prime}$ & 0.2 & N-W \\
\hline 18 & $42^{\circ} 19^{\prime} 24.1^{\prime \prime}$ & $317^{\circ} 40^{\prime} 35.9^{\prime \prime}$ & 0.21 & N-W \\
\hline 19 & $42^{\circ} 19^{\prime} 21.7^{\prime \prime}$ & $317^{\circ} 40^{\prime} 38.3^{\prime \prime}$ & 0.19 & N-W \\
\hline 20 & $77^{\circ} 2^{\prime} 57.3^{\prime \prime}$ & $282^{\circ} 57^{\prime} 3.7^{\prime \prime}$ & 0.16 & N-W \\
\hline 21 & $4^{\circ} 27^{\prime} 47.9^{\prime \prime}$ & $355^{\circ} 32^{\prime} 12.1^{\prime \prime}$ & 0.27 & N-W \\
\hline 22 & $32^{\circ} 5^{\prime} 46.7^{\prime \prime}$ & $327^{\circ} 54^{\prime} 13.3^{\prime \prime}$ & 0.12 & N-W \\
\hline 23 & $0^{\circ} 31^{\prime} 45.4^{\prime \prime}$ & $359^{\circ} 28^{\prime} 14.6^{\prime \prime}$ & 0.01 & N-W \\
\hline 24 & $41^{\circ} 15^{\prime} 19.6^{\prime \prime}$ & $41^{\circ} 15^{\prime} 19.6^{\prime \prime}$ & 0.05 & N-E \\
\hline 25 & $47^{\circ} 38^{\prime} 2.1^{\prime \prime}$ & $47^{\circ} 38^{\prime} 2.1^{\prime \prime}$ & 0.13 & N-E \\
\hline 26 & $24^{\circ} 36^{\prime} 21.2^{\prime \prime}$ & $335^{\circ} 23^{\prime} 38.8^{\prime \prime}$ & 0.21 & N-W \\
\hline 27 & $42^{\circ} 18^{\prime} 52.9^{\prime \prime}$ & $317^{\circ} 41^{\prime} 7.1^{\prime \prime}$ & 0.23 & N-W \\
\hline 28 & $42^{\circ} 18^{\prime} 51.1^{\prime \prime}$ & $317^{\circ} 41^{\prime} 8.9^{\prime \prime}$ & 0.24 & N-W \\
\hline 29 & $42^{\circ} 18^{\prime} 47.7^{\prime \prime}$ & $317^{\circ} 41^{\prime} 13.3^{\prime \prime}$ & 0.26 & N-W \\
\hline 30 & $42^{\circ} 18^{\prime} 43.8^{\prime \prime}$ & $317^{\circ} 41^{\prime} 16.2^{\prime \prime}$ & 0.3 & N-W \\
\hline 31 & $6^{\circ} 3^{\prime} 42.5^{\prime \prime}$ & $353^{\circ} 56^{\prime} 17.5^{\prime \prime}$ & 0.34 & N-W \\
\hline 32 & $34^{\circ} 21^{\prime} 3.0^{\prime \prime}$ & $325^{\circ} 38^{\prime} 57^{\prime \prime}$ & 0.81 & N-W \\
\hline 33 & $26^{\circ} 55^{\prime} 18.7^{\prime \prime}$ & $333^{\circ} 4^{\prime} 41.3^{\prime \prime}$ & 0.85 & N-W \\
\hline 34 & $56^{\circ} 38^{\prime} 9.2^{\prime \prime}$ & $303^{\circ} 21^{\prime} 50.9^{\prime \prime}$ & 0.92 & N-W \\
\hline 35 & $64^{\circ} 53^{\prime} 24.2^{\prime \prime}$ & $295^{\circ} 6^{\prime} 35.9^{\prime \prime}$ & 0.88 & N-W \\
\hline 36 & $49^{\circ} 57^{\prime} 7.8^{\prime \prime}$ & $310^{\circ} 2^{\prime} 52.2^{\prime \prime}$ & 0.77 & N-W \\
\hline
\end{tabular}




\section{Continued}

\begin{tabular}{|c|c|c|c|c|}
\hline 37 & $43^{\circ} 36^{\prime} 34.2^{\prime \prime}$ & $316^{\circ} 23^{\prime} 25.8^{\prime \prime}$ & 0.57 & N-W \\
\hline 38 & $55^{\circ} 6^{\prime} 28.7^{\prime \prime}$ & $304^{\circ} 53^{\prime} 31.3^{\prime \prime}$ & 0.55 & N-W \\
\hline 39 & $59^{\circ} 5^{\prime} 58.8^{\prime \prime}$ & $300^{\circ} 54^{\prime} 1.2^{\prime \prime}$ & 0.23 & N-W \\
\hline 40 & $80^{\circ} 29^{\prime} 4.6^{\prime \prime}$ & $279^{\circ} 30^{\prime} 55.4^{\prime \prime}$ & 0.08 & N-W \\
\hline 41 & $89^{\circ} 29^{\prime} 29.7^{\prime \prime}$ & $269^{\circ} 29^{\prime} 29.7^{\prime \prime}$ & 0.09 & S-W \\
\hline 42 & $83^{\circ} 0^{\prime} 11.7^{\prime \prime}$ & $276^{\circ} 59^{\prime} 48.3^{\prime \prime}$ & 0.17 & N-W \\
\hline 43 & $58^{\circ} 24^{\prime} 37.2^{\prime \prime}$ & $238^{\circ} 24^{\prime} 37.2$ & 0.38 & S-W \\
\hline 44 & $58^{\circ} 37^{\prime} 16.0^{\prime \prime}$ & $301^{\circ} 22^{\prime} 44^{\prime \prime}$ & 0.68 & N-W \\
\hline 45 & $51^{\circ} 51^{\prime} 2.8^{\prime \prime}$ & $308^{\circ} 8^{\prime} 57.2^{\prime \prime}$ & 0.75 & N-W \\
\hline 46 & $89^{\circ} 29^{\prime} 57.1^{\prime \prime}$ & $269^{\circ} 29^{\prime} 57.1^{\prime \prime}$ & 0.72 & S-W \\
\hline 47 & $52^{\circ} 45^{\prime} 39.6^{\prime \prime}$ & $232^{\circ} 45^{\prime} 39.6^{\prime \prime}$ & 0.76 & S-W \\
\hline 48 & $30^{\circ} 6^{\prime} 36.2^{\prime \prime}$ & $329^{\circ} 53^{\prime} 23.8^{\prime \prime}$ & 0.79 & N-W \\
\hline 49 & $13^{\circ} 4^{\prime} 58.8^{\prime \prime}$ & $346^{\circ} 55^{\prime} 1.2^{\prime \prime}$ & 0.58 & N-W \\
\hline 50 & $89^{\circ} 30^{\prime} 14.3^{\prime \prime}$ & $269^{\circ} 30^{\prime} 14.3^{\prime \prime}$ & 0.5 & S-W \\
\hline 51 & $81^{\circ} 32^{\prime} 15.5^{\prime \prime}$ & $260^{\circ} 32^{\prime} 15.5^{\prime \prime}$ & 0.61 & S-W \\
\hline 52 & $42^{\circ} 15^{\prime} 35.5^{\prime \prime}$ & $317^{\circ} 44^{\prime} 24.5^{\prime \prime}$ & 0.68 & N-W \\
\hline 53 & $48^{\circ} 38^{\prime} 18.9^{\prime \prime}$ & $311^{\circ} 21^{\prime} 41.1^{\prime \prime}$ & 0.69 & N-W \\
\hline 54 & $73^{\circ} 51^{\prime} 57.1^{\prime \prime}$ & $286^{\circ} 8^{\prime} 41.1^{\prime \prime}$ & 0.7 & N-W \\
\hline 55 & $42^{\circ} 15^{\prime} 22.0^{\prime \prime}$ & $317^{\circ} 44^{\prime} 38.1^{\prime \prime}$ & 0.8 & N-W \\
\hline 56 & $36^{\circ} 38^{\prime} 34.9^{\prime \prime}$ & $323^{\circ} 21^{\prime} 25.1^{\prime \prime}$ & 0.76 & N-W \\
\hline 57 & $19^{\circ} 0^{\prime} 11.3^{\prime \prime}$ & $340^{\circ} 59^{\prime} 48.7^{\prime \prime}$ & 0.67 & N-W \\
\hline 58 & $36^{\circ} 1^{\prime} 46.5^{\prime \prime}$ & $323^{\circ} 58^{\prime} 13.5^{\prime \prime}$ & 0.59 & N-W \\
\hline 59 & $7^{\circ} 19^{\prime} 59.1 "$ & $7^{\circ} 19^{\prime} 59.1 "$ & 0.57 & N-E \\
\hline 60 & $49^{\circ} 25^{\prime} 42.5^{\prime \prime}$ & $310^{\circ} 34^{\prime} 17.5^{\prime \prime}$ & 0.19 & N-W \\
\hline 61 & $83^{\circ} 23^{\prime} 29.4^{\prime \prime}$ & $276^{\circ} 36^{\prime} 30.6^{\prime \prime}$ & 0.26 & N-W \\
\hline 62 & $59^{\circ} 57^{\prime} 52.6^{\prime \prime}$ & $300^{\circ} 2^{\prime} 7.4^{\prime \prime}$ & 0.3 & N-W \\
\hline 63 & $61^{\circ} 13^{\prime} 56.6^{\prime \prime}$ & $298^{\circ} 46^{\prime} 3.4^{\prime \prime}$ & 0.31 & N-W \\
\hline 64 & $42^{\circ} 14^{\prime} 26.9^{\prime \prime}$ & $317^{\circ} 45^{\prime} 33.1^{\prime \prime}$ & 0.31 & N-W \\
\hline 65 & $52^{\circ} 46^{\prime} 12.4^{\prime \prime}$ & $232^{\circ} 45^{\prime} 12.4^{\prime \prime}$ & 0.31 & S-W \\
\hline 66 & $79^{\circ} 54^{\prime} 21.7^{\prime \prime}$ & $280^{\circ} 5^{\prime} 38.2^{\prime \prime}$ & 0.41 & N-W \\
\hline 67 & $89^{\circ} 31^{\prime} 16.3^{\prime \prime}$ & $269^{\circ} 31^{\prime} 16.3^{\prime \prime}$ & 0.47 & S-W \\
\hline 68 & $33^{\circ} 0^{\prime} 16.3^{\prime \prime}$ & $326^{\circ} 59^{\prime} 43.7^{\prime \prime}$ & 0.51 & N-W \\
\hline 69 & $0^{\circ} 28^{\prime} 39.9^{\prime \prime}$ & $359^{\circ} 31^{\prime} 20.1^{\prime \prime}$ & 0.44 & N-W \\
\hline 70 & $30^{\circ} 4^{\prime} 47.3^{\prime \prime}$ & $329^{\circ} 55^{\prime} 12.7^{\prime \prime}$ & 0.43 & N-W \\
\hline 71 & $53^{\circ} 43^{\prime} 35.8^{\prime \prime}$ & $306^{\circ} 16^{\prime} 24.2^{\prime \prime}$ & 0.4 & N-W \\
\hline 72 & $38^{\circ} 28^{\prime} 18.9^{\prime \prime}$ & $321^{\circ} 31^{\prime} 41.5^{\prime \prime}$ & 0.41 & N-W \\
\hline 73 & $0^{\circ} 28^{\prime} 32.5^{\prime \prime}$ & $359^{\circ} 31^{\prime} 27.5^{\prime \prime}$ & 0.44 & N-W \\
\hline
\end{tabular}


Continued

\begin{tabular}{|c|c|c|c|c|}
\hline 74 & $30^{\circ} 4^{\prime} 33.9^{\prime \prime}$ & $329^{\circ} 55^{\prime} 26.1^{\prime \prime}$ & 0.39 & N-W \\
\hline 75 & $12^{\circ} 6^{\prime} 20.6^{\prime \prime}$ & $12^{\circ} 6^{\prime} 20.6^{\prime \prime}$ & 0.43 & N-E \\
\hline 76 & $42^{\circ} 13^{\prime} 47.7^{\prime \prime}$ & $317^{\circ} 46^{\prime} 12.3^{\prime \prime}$ & 0.29 & $\mathrm{~N}-\mathrm{W}$ \\
\hline 77 & $47^{\circ} 0^{\prime} 23.6^{\prime \prime}$ & $312^{\circ} 59^{\prime} 36.4^{\prime \prime}$ & 0.31 & N-W \\
\hline 78 & $58^{\circ} 34^{\prime} 34.0^{\prime \prime}$ & $301^{\circ} 25^{\prime} 26^{\prime \prime}$ & 0.5 & N-W \\
\hline 79 & $78^{\circ} 57^{\prime} 7.6^{\prime \prime}$ & $258^{\circ} 57^{\prime} 7.6^{\prime \prime}$ & 0.62 & S-W \\
\hline 80 & $76^{\circ} 29^{\prime} 29.2^{\prime \prime}$ & $283^{\circ} 30^{\prime} 30.8^{\prime \prime}$ & 0.71 & N-W \\
\hline 81 & $61^{\circ} 12^{\prime} 55.9^{\prime \prime}$ & $298^{\circ} 47^{\prime} 4.1^{\prime \prime}$ & 0.72 & $\mathrm{~N}-\mathrm{W}$ \\
\hline 82 & $64^{\circ} 49^{\prime} 23.4^{\prime \prime}$ & $295^{\circ} 10^{\prime} 36.6^{\prime \prime}$ & 0.69 & N-W \\
\hline 83 & $46^{\circ} 18^{\prime} 48.4^{\prime \prime}$ & $313^{\circ} 41^{\prime} 11.6^{\prime \prime}$ & 0.69 & N-W \\
\hline 84 & $0^{\circ} 28^{\prime} 2.7^{\prime \prime}$ & $359^{\circ} 31^{\prime} 57.3^{\prime \prime}$ & 0.79 & N-W \\
\hline 85 & $40^{\circ} 7^{\prime} 9.1^{\prime \prime}$ & $319^{\circ} 52^{\prime} 50.9^{\prime \prime}$ & 0.69 & N-W \\
\hline 86 & $45^{\circ} 34^{\prime} 58.7^{\prime \prime}$ & $314^{\circ} 25^{\prime} 1.3^{\prime \prime}$ & 0.65 & N-W \\
\hline 87 & $42^{\circ} 12^{\prime} 52.6^{\prime \prime}$ & $317^{\circ} 47^{\prime} 7.4^{\prime \prime}$ & 0.62 & N-W \\
\hline 88 & $42^{\circ} 12^{\prime} 50.8^{\prime \prime}$ & $317^{\circ} 47^{\prime} 9.2^{\prime \prime}$ & 0.61 & N-W \\
\hline 89 & $69^{\circ} 59^{\prime} 4.9^{\prime \prime}$ & $290^{\circ} 0^{\prime} 55.1^{\prime \prime}$ & 0.6 & N-W \\
\hline 90 & $17^{\circ} 1^{\prime} 53.2^{\prime \prime}$ & $342^{\circ} 58^{\prime} 6.8^{\prime \prime}$ & 0.62 & N-W \\
\hline 91 & $74^{\circ} 48^{\prime} 53.2^{\prime \prime}$ & $285^{\circ} 11^{\prime} 6.8^{\prime \prime}$ & 0.48 & N-W \\
\hline 92 & $17^{\circ} 1^{\prime} 49.1^{\prime \prime}$ & $342^{\circ} 58^{\prime} 10.9^{\prime \prime}$ & 0.53 & N-W \\
\hline 93 & $45^{\circ} 13^{\prime} 17.9^{\prime \prime}$ & $314^{\circ} 46^{\prime} 42.1^{\prime \prime}$ & 0.52 & N-W \\
\hline 94 & $2^{\circ} 56^{\prime} 36.3^{\prime \prime}$ & $357^{\circ} 3^{\prime} 23.7^{\prime \prime}$ & 0.5 & N-W \\
\hline 95 & $24^{\circ} 30^{\prime} 30.7^{\prime \prime}$ & $335^{\circ} 29^{\prime} 29.3^{\prime \prime}$ & 0.22 & N-W \\
\hline 96 & $17^{\circ} 1^{\prime} 38.9^{\prime \prime}$ & $342^{\circ} 58^{\prime} 21.1 "$ & 0.18 & N-W \\
\hline 97 & $42^{\circ} 12^{\prime} 26.0^{\prime \prime}$ & $317^{\circ} 47^{\prime} 34^{\prime \prime}$ & 0.16 & N-W \\
\hline 98 & $13^{\circ} 2^{\prime} 15.1^{\prime \prime}$ & $346^{\circ} 57^{\prime} 44.9^{\prime \prime}$ & 0.16 & N-W \\
\hline 99 & $89^{\circ} 13^{\prime} 11.7^{\prime \prime}$ & $89^{\circ} 13^{\prime} 37.7^{\prime \prime}$ & 0.03 & N-E \\
\hline 100 & $89^{\circ} 19^{\prime} 37.4^{\prime \prime}$ & $269^{\circ} 19^{\prime} 37.4^{\prime \prime}$ & 0 & - \\
\hline 101 & $51^{\circ} 25^{\prime} 37.1^{\prime \prime}$ & $51^{\circ} 25^{\prime} 37.1^{\prime \prime}$ & 0.05 & $\mathrm{~N}-\mathrm{E}$ \\
\hline 102 & $44^{\circ} 57^{\prime} 18.4^{\prime \prime}$ & $135^{\circ} 2^{\prime} 41.6^{\prime \prime}$ & 0.35 & S-E \\
\hline
\end{tabular}

T-index value is 0 .

For AHP comparison matrix, six parameters have taken into consideration (Table 5 and Table 6), for their morphotectonic behaviors. From the AHP analysis it is found that the basin shape index (Bs) shows active tectonic influence and it rank 1st. The Mountain front sinuosity (Mfs) ranks second and has significant active tectonic influence. The Kakoi River channel is twisty and it indicates that the lithology and the tectonic plays important role while flowing through the alluvial plain. Elongation ratio $\left(R_{e}\right)$ of the Kakoi watershed has indicated that the watershed has less influence from recent active tectonic rather 
Table 5. AHP comparison for different morphometric indices.

\begin{tabular}{|c|c|c|c|c|c|c|c|}
\hline \multicolumn{2}{|c|}{ Perimeter } & \multirow{2}{*}{$\begin{array}{l}\text { Mfs } \\
2.02\end{array}$} & \multirow{2}{*}{$\begin{array}{c}S \\
1.38\end{array}$} & \multirow{2}{*}{$\begin{array}{c}\mathrm{Vf} \\
0.301\end{array}$} & \multirow{2}{*}{$\begin{array}{c}\mathrm{R}_{\mathrm{e}} \\
0.461\end{array}$} & \multirow{2}{*}{$\begin{array}{l}\text { Bs } \\
3.6\end{array}$} & \multirow{2}{*}{$\begin{array}{c}\mathrm{HI} \\
0.45\end{array}$} \\
\hline & Value & & & & & & \\
\hline Mfs & 2.02 & 1.00 & 1.46 & 6.71 & 4.38 & 0.56 & 4.49 \\
\hline$S$ & 1.38 & 0.68 & 1.00 & 4.58 & 2.99 & 0.38 & 3.07 \\
\hline $\mathrm{Vf}$ & 0.301 & 0.15 & 0.22 & 1.00 & 0.65 & 0.08 & 0.67 \\
\hline $\mathrm{Rl}$ & 0.461 & 0.23 & 0.33 & 1.53 & 1.00 & 0.13 & 1.02 \\
\hline Bs & 3.6 & 1.78 & 2.61 & 11.96 & 7.81 & 1.00 & 8.00 \\
\hline $\mathrm{HI}$ & 0.45 & 0.22 & 0.33 & 1.50 & 0.98 & 0.13 & 1.00 \\
\hline \multicolumn{2}{|c|}{ Total } & 4.07 & 5.95 & 27.28 & 17.81 & 2.28 & 18.25 \\
\hline
\end{tabular}

Table 6. AHP weight and rank for different geomorphic indices.

\begin{tabular}{ccccccccccc}
\hline Perimeter & & & & & & & Sum & Weight & $\%$ & Rank \\
\hline Mfs & 0.25 & 0.25 & 0.25 & 0.25 & 0.25 & 0.25 & 1.48 & 0.25 & 24.60 & 2 \\
S & 0.17 & 0.17 & 0.17 & 0.17 & 0.17 & 0.17 & 1.01 & 0.17 & 16.80 & 3 \\
Vf & 0.04 & 0.04 & 0.04 & 0.04 & 0.04 & 0.04 & 0.22 & 0.04 & 3.67 & 6 \\
$\mathbf{R}_{\mathbf{e}}$ & 0.06 & 0.06 & 0.06 & 0.06 & 0.06 & 0.06 & 0.34 & 0.06 & 5.61 & 4 \\
Bs & 0.44 & 0.44 & 0.44 & 0.44 & 0.44 & 0.44 & 2.63 & 0.44 & 43.84 & 1 \\
HI & 0.05 & 0.05 & 0.05 & 0.05 & 0.05 & 0.05 & 0.33 & 0.05 & 5.48 & 5 \\
& & & & & & & & & & \\
\end{tabular}

lithology plays important role. $\mathrm{Hl}$ and $\mathrm{Vf}$ has shown less influence of tectonic activity. Most of the basin area is low laying plain where lithology plays important role in the evolution of the basin. Erosion and deposition is the main activity which influence the landscape of the basin.

\section{Discussion and Conclusions}

The morphometric analysis of the Kakoi River basin has indicated that the basis has undergone dynamic changes from both lithology and active tectonic activity. The northern part of the basin has high relief with maximum $1728 \mathrm{~m}$ and part of lower Himalaya mountain range. These regions are continuously uplifted because of the Indian plate movement towards the Eurasia plate. As a result, thrust is created along the foot hills of the lower Himalaya range. The mountain front sinuosity ( $\mathrm{mfs}$ ) indicates the present of active tectonic in the north part of the basin. The valley floor ( $\mathrm{Vf}$ ) ratio also indicates that the presence of high tectonic activity at the northern part of the basin where $\mathrm{V}$ shape valley has formed. Highly dissected and structural hill is the physiographic characteristic of the northern part of the basin.

Most of the area of the basin is low-lying alluvial plain with low relief in the southern part. The lithology plays an important role in modifying the landscape rather than active tectonics. Deposition and erosion are the main activities dur- 
ing the monsoon season in this area. The deposition of the sediment along the river bed decreases the depth of the river. As a result, the overflow of water during the monsoon season is common in this area. The dipping of sedimentary layers during runoff may be the other reason for the tilting of the basin.

The migration of the river course is more prominent in the alluvial plain of the basin than the hilly region in the north. The lithology plays an important role along with significant active tectonic activity in river course migration. Most part of the river course is migrated towards north-west and south-west direction. Lastly we can conclude that the basin area is controlled by active tectonic as well as lithology. This present study has been carried out based on morphometric analysis (surface features anomalies). However, detailed subsurface lithological, structural, and geophysical studies are required to analyze the micro and mega scale changes of watershed, which are helpful for sustainable watershed development especially in tectonically active regions.

\section{Acknowledgements}

Authors are thankful to Director and Dean (R \& D), TISS for financial support to carry out this research. We are thankful to anonymous reviewers for spending valuable time and suggestions to complete the manuscript successfully.

\section{References}

[1] Agarwal, C.S. (1998) Study of Drainage Pattern through Aerial Data in Naugarh Area of Varanasi District, U.P. Journal of the Indian Society of Remote Sensing, 26,169-175. https://doi.org/10.1007/BF02990795

[2] Obi Reddy, G.E., Maji, A.K. and Gajbhiye, K.S, (2002) GIS for Morphometric Analysis of Drainage Basins. GIS India, 11, 9-14.

[3] Pakhmode, V., Kulkarni, H. and Deolankar, S.B. (2003) Hydrological Drainage Analysis in Watershed-Programme Planning: A Case from the Deccan Basalt, India. Hydrogeology Journal, 11, 595-604. https://doi.org/10.1007/s10040-003-0279-Z

[4] Horton, R.E. (1932) Drainage Basin Characteristics. Transactions-American Geophysical Union, 13, 350-361.

[5] Horton, R.E. (1945) Erosional Development of Streams and Their Drainage Basins: A Hydrophysical Approach to Quantitative Morphology. Geological Society of American Bulletin, 56, 275-370. https://doi.org/10.1130/0016-7606(1945)56[275:EDOSAT]2.0.CO;2

[6] Schumm, S.A. (1956) Evolution of Drainage Systems and Slopes in Badlands at Perth Amboy, New Jersey. Geological Society of America Bulletin, 67, 597-646. https://doi.org/10.1130/0016-7606(1956)67[597:EODSAS]2.0.CO;2

[7] Rastogi, R.A. and Sharma, T.C. (1976) Quantitative Analysis of Drainage Basin Characteristics. Journal of Soil and Water Conservation in India, 26, 18-25.

[8] Altaf, F., Meraj, G. and Romshoo, S.A. (2013) Morphometric Analysis to Infer Hydrological Behaviour of Lidder Watershed, Western Himalaya, India. Geography Journal, 2013, Article ID: 178021.

[9] Singh, S. (1992) Quantitative Geomorphology of the Drainage Basin. In: Chouhan T.S., and Joshi, K.N., Eds., Readings on Remote Sensing Applications, Scientific 
Publishers, Jodhpur.

[10] Dar, R.A., Chandra, R. and Romshoo, S.A. (2013) Morphotectonic and Litho-Stratigraphic Analysis of Inter-Montane Karewa Basin of Kashmir Himalayas, India. Journal of Mountain Science, 10, 1-15. https://doi.org/10.1007/s11629-013-2494-y

[11] Romshoo, S.A., Bhat, S.A. and Rashid, I. (2012) Geoinformatics for Assessing the Morphometric Control on Hydrological Response at Watershed Scale in the Upper Indus Basin. Journal of Earth System Science, 121, 659-686. https://doi.org/10.1007/s12040-012-0192-8

[12] Bahrami, S. (2013) Analyzing the Drainage System Anomaly of Zagros Basins: Implications for Active Tectonics. Tectonophysics, 608, 914-928. https://doi.org/10.1016/j.tecto.2013.07.026

[13] Baioni, D. (2007) Drainage Basin Asymmetry and Erosion Processes Relationship through a New Representation of Two Geomorphic Indices in the Conca River (Northern Apennines). Italian Journal of Geosciences, 126, 573-579.

[14] Raju, G.S. and Babu, K.R. (2012) Morphometric Analysis of Kunderu River Basin, Kurnool District, A.P, India for Watershed Management. Journal of Environmental Science \& Engineering, 54, 85-89.

[15] Keller, E.A. and Pinter, N. (1996) Active Tectonics: Earthquakes, Uplift, and Landscape. Prentice Hall.

[16] Bhat, F.A., Bhat, I.M., Sana, H., Iqbal, M. and Mir, A.R. (2013) Identification of Geomorphic Signatures of Active Tectonics in the West Lidder Watershed, Kashmir Himalayas: Using Remote Sensing and GIS. International Journal of Geomatics and Geosciences, 4,164-176.

[17] Bull, W.B. and McFadden, L.D. (1977) Tectonic Geomorphology North and South of the Garlock Fault, California. Geomorphology in Arid Regions. In: Doehring, D.O., Ed., Proceedings of the Eight Annual Geomorphology Symposium, State University of New York at Binghamton, Binghamton, 115-138.

[18] Parkash, B. and Kumar, S. (1991) Lndogangetic Basin. In: Tandon, S.K., Pant, C.C. and Casshyap, S., Eds., Sedimentary Basins of India; Tectonic Context, Gyanodaya Prakashan, Nainital, 147-170.

[19] Pankaj, S., Prakash, B., Sehgal, J.L. and Sudhir, K. (1994) Role of Neotectonics and Climate in Development of the Holocene Geomorphology and Soils of the Gangetic Plains between the Ramganga and Rapti Rivers. Sendimentary Geology, 94, 129-151. https://doi.org/10.1016/0037-0738(94)90151-1

[20] Garde, R.J. (2006) River Morphology. New Age International (P) Ltd., 388.

[21] Building Material \& Technology Promotion Board (2003) Vulnerabilty Atlas. 2nd Edition, Peer Group, MoH \& UPA; Seismic Zones of India IS: 1983-2002, BIS, GOI, Seismotectonic Atlas of India and Its Environs, GSI, GOI.

[22] Roy, T.K. (1975) Drainage Analysis in the Upper Assam Valley. Indian Journal of Earth Sciences, 2, 39-50.

[23] Sarma, J.N. and Basumallick, S. (1984) Drainage Analysis of the Areas around the Burhi Dihing River Catchment India. Indian Journal of Earth Science, 11, 79-86.

[24] Kunte, S.V. (1988) Geomorphic Analysis of Upper Assam Plains and Adjoining Areas for Hydrocarbon Exploration. Journal of the Indian Society of Remote Sensing, 16, 15-28. https://doi.org/10.1007/BF02992097

[25] Pahari, S., Singh, H., Prasad, I.V.S.V. and Singh, R.R. (2008) Petroleum Systems of Upper Assam Shelf, India. Society of Petroleum Geophysicist, India. Geo-Horizons, 
14-21.

[26] Poddar, M.C. (1952) Preliminary Report of the Assam Earthquake of 15th August, 1950. Journal of the Geological Society of India, 2, 11-13.

[27] Das, A.K. and Mukherjee, S. (2005) Drainage Morphometry using Satellite Data and GIS in Raigaddistrict, Maharashtra. Journal of the Geological Society of India, 65, 577-586.

[28] Vittala, S.S., Govindaih, S. and Gowda, H.H. (2004) Morphometric Analysis of Sub-Watershed in the Pavada Area of Tumkur District, South India using Remote Sensing and GIS Techniques. Journal of Indian Remote Sensing, 32, 351-362. https://doi.org/10.1007/BF03030860

[29] Central Ground Water Board NE Region (2013) Ground Water Information Booklet Lakhimpur District, Assam. Technical Reports Series: D. Ministry of Water Resourse, Govt. of Assam.

[30] Roy Guha, P.K. (1969) A Note on the Geohydrlogical Investigation for Water Supply in the Seajuli Tea Estate, Lakimpur District, Assam. Geological Survey of India, GSI-CHQ-15483.

[31] Detailed Project Report of Lakhimpur-8 (Korha Champora), IWMP (2011-2017) State Level Nodal Agency, Assam.

[32] Evans Gayla, A., Ramachandran, B., Zhang, Z., Bailey, G.B. and Cheng, P. (2008) An Accuracy Assessment of Cartosat-1 Stereo Image Data-Derived Digital Elevation Models: A Case Study of the Drum Mountains, Utah. The International Archives of the Photogrammetry, Remote Sensing and Spatial Information Sciences, 37, 1161-1164.

[33] Gajalakshmi, K. and Anantharama, V. (2015) Comparative Study of Cartosat-DEM and SRTM-DEM on Elevation Data and Terrain Elements. International Journal of Advanced Remote Sensing and GIS, 4, 1361-1366.

https://doi.org/10.23953/cloud.ijarsg.123

[34] Baral, S.S., Das, J., Saraf, A.K., Borgohain, S. and Singh, G. (2016) Comparison of Cartosat, ASTER and SRTM DEMs of Different Terrains. Asian Journal of Geoinformatics, 16, 2-7.

[35] Strahler, A.N. (1952) Quantitative Analysis of Watershed Geomorpology. Transactions of the American Geophysical Union, 38, 913-920. https://doi.org/10.1029/TR038i006p00913

[36] Leopold, L.B., Wolman, M.G. and Miller, J.P. (1964) Fluvial Processes in Geomorphology. W.H. Freeman and Co., San Francisco.

[37] Keller, E.A. and Pinter, N. (2002) Active Tectonics: Earthquakes and Landscape. 2nd Edition, Prentice-Hall, Upper Saddle River.

[38] Hack, J.T. (1973) Stream-Profiles Analysis and Stream-Gradient Index. Journal of Research of the U.S. Geological Survey, 1, 421-429.

[39] Kale, V.S. and Shejwalkar, N. (2008) Uplift along the Western Margin of the Deccan Basalt Province: Is There Any Geomorphometric Evidence? Journal of Earth System Sciences, 117, 959-971. https://doi.org/10.1007/s12040-008-0081-3

[40] El. Hamdouni, R., Irigaray, C., Fernandez, T., Chacón, J. and Keller, E. (2007) Assessment of Relative Active Tectonics, Southwest Border of Sierra Nevada (Southern Spain). Geomorphology, 96, 150-173. https://doi.org/10.1016/j.geomorph.2007.08.004

[41] Gardner, R.H., Milne, B.T., O’Neill, R.V. and Turner, M.G. (1987) Neutral Models for the Analysis of Broad Scale Landscape Patterns. Landscape Ecology, 1, 19-28. 
https://doi.org/10.1007/BF02275262

[42] Cox, R.T. (1994) Analysis of Drainage Basin Symmetry as a Rapid Technique to Identify Areas of Possible Quaternary Tilt-Block Tectonics: An Example from the Mississipi Embayment. Geological Society of America Bulletin, 106, 571-581. https://doi.org/10.1130/0016-7606(1994)106<0571:AODBSA>2.3.CO;2

[43] Saaty, T.L. (1977) A Scaling Method for Priorities in Hierarchical Structures. Journal of Mathematical Psychology, 15, 57-68.

https://doi.org/10.1016/0022-2496(77)90033-5 